\title{
The chain tower in Kyrenia's harbour, Cyprus
}

\author{
Alessandro Camiz ${ }^{\text {a }}$, Marika Griffo ${ }^{b}$, Seda Baydur ${ }^{\text {c }}$, Emilia Valletta ${ }^{\text {d }}$ \\ a Özyeğin Üniversitesi, Istanbul, Turkey, alessandro.camiz@ozyegin.edu.tr \\ b Sapienza Università di Roma, Rome, Italy, marika.griffo@uniroma1.it \\ ${ }^{\mathrm{c}}$ Kadir Has Üniversitesi, Istanbul, Turkey, sedabaydur@outlook.com \\ ${ }^{\mathrm{d}}$ Scuola di Specializzazione in Beni Architettonici e del Paesaggio, Sapienza Università di Roma, Rome, Italy, \\ emiliavalletta@hotmail.it
}

\begin{abstract}
In the Middle Ages a chain suspended between two towers defended the entrance of Kyrenia's little harbour, like the chain across the Golden Horn in Constantinople. William de Oldenburg, who visited Cyprus in 1211 during the reign of King Hugh I, referred to Kyrenia as "a small town well-fortified, which has a castle with walls and towers". He perceived the chain tower as part of Kyrenia's fortification system in that time. The Byzantines had already fortified the city, but in the thirteenth century, during the Longobard war, before the siege of the city, Frederick II's party, under the direction of Captain Philippo Genardo, improved the defences of the city. The chain tower is still visible today in the north side of the old Kyrenia harbour. It consists of an 8,15 m diameter cylindrical tower and a 1,5 m diameter pillar on top of it. The tower was supporting a chain attached on the other side to another structure. The fortifications on the north side terminated against the harbour in a square tower or bastion holding the chain to be raised and lowered by means of a windlass. The paper includes the digital photogrammetric survey of the chain tower using a structure from motion software, the historical research and the comparison with other coeval harbour defence constructions of the eastern Mediterranean.
\end{abstract}

Keywords: Military architecture, photogrammetric survey, history.

\section{Introduction}

Protected by a natural inlet, Kyrenia's ancient harbour (Girne) is to this day the hub of economic and social life within the old city. At the end of the Eastern breakwater still stands a Chain Tower, so called because of a chain anchored to it and closing the entrance to the harbour. The tower was part of the town fortifications, a complex structure most probably started in Byzantine times and enlarged during the Lusignan rule between the twelfth and fourteenth centuries (Enlart, 1899). During the centuries, it was severely ruined by the action of the sea, and was thoroughly restored in 1937 by the Department of Antiquities. The tower's actual facies is not indeed the original one, but the result of a restoration project. The outer surface of the structure, built entirely in masonry of local calcarenithic ashlars, belongs to this restoration phase, as added to enclose the remnants of the original tower. We should note that the iconic character of this tower, it currently is the emblem of Girne's Municipality, is the excellent result of a conservation operation not only restoring the construction's matter but also reintegrating its picture (Carbonara, 1979). A medieval traveller visiting Kyrenia during the reign of Hugh IV, when the Latin Kingdom of Cyprus was flourishing, would have landed on a quay 
surrounded by a compact urban tissue, some traces of which may be detected in the massive arches of the old store row-houses embedded into the existing buildings. In the fourteenth century, the little port was protected on the seaside by a mole, and a chain. The other land fortifications are at present day mostly ruined fragments, while on the eastern side of the town stood the rectangular Castle equipped with four circular towers, as it was before the transformation accomplished by the Venetian engineers in the second half of the sixteenth century (Camiz, Khalil, Demir, Nafa, 2016). Perhaps the first reliable medieval reference to the fortress of Kyrenia occurs in the travels of W. de Oldenburg, who visited Cyprus in 1211, during the reign of King Hugh I. He refers to Kyrenia as "a small town well-fortified, which has a castle with walls and towers, its chief boast is a good harbour". A wall enclosed the town on its western and southern sides, and the massive southwest angle tower still stands. On the southern wall, there may have been one or more towers, but these fortifications were demolished in Venetian times when the defence was redefined within the castle (Jeffery, 1918). The Chain Tower has a circular plan of roughly $8 \mathrm{~m}$ diameter and $5 \mathrm{~m}$ height. On top of the tower, a Doric column with a bugnato surface reveals in its neoclassical style the time of its construction at the end of the nineteenth century. In the time of its activity, the chain would have been suspended across the harbour mouth between this solid round tower and a square tower or lighthouse on the ancient pier for a total length of approximately three hundred feet. The heavy iron chain was suspended right across the port entrance and connected with a windlass in a stone building on the site of the present Custom House. The chain was raised to impede hostile ships from entering the port, and eventually lowered to allow allies to access the port facilities. The concept of stretching a heavy long boom or similar obstacle across a large body of water has been a building technique in use for centuries. For more than a thousand years and even going back to Roman times, when pirates infested the Mediterranean sea. This depended on the lack properly organised state navies; while instead, there were groups of rich merchants in each port who armed themselves. Therefore, the idea of the chain came to ensure the protection the ports from these common pirate incursions.

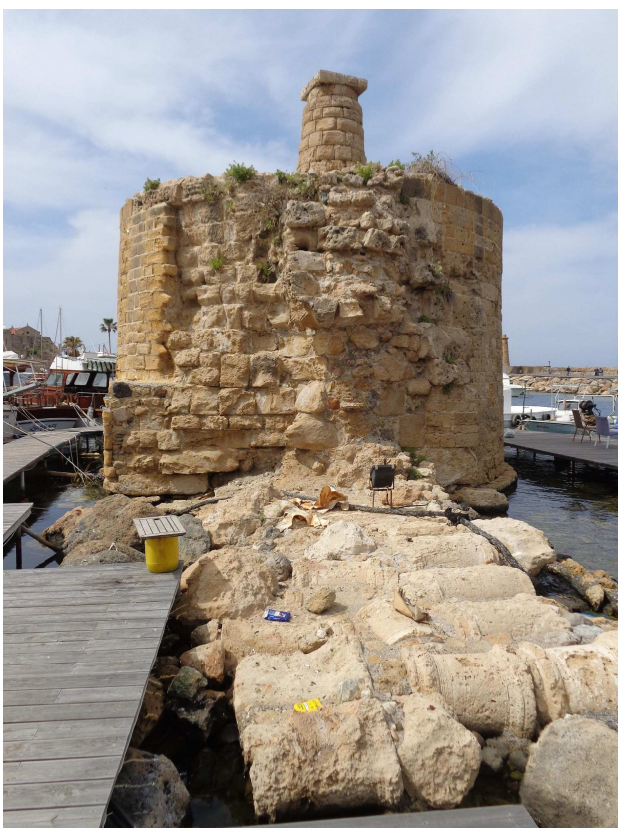

Fig. 1. Roman stone column bases were recycled for the foundations of the dock (Photo A. Camiz, 2018).

An iron chain protected the entrance of the Golden Horn in Constantinople since the fifth century AD The chain was anchored on both ends to large fortified towers: one is the Galata tower, which survives in the foundations of Yeralti Camii, not to be confused with today's Galata tower, built by the Genoese in the fourteenth century. Ludwig of Bavaria installed another chain across the river Rhine in Germany in 1326-1327, when castles guarded the routes taken by sailing ships. At this point, if any boat crossing the rivers did not pay the toll, this large iron chain, lying on the water and ready to be towed at any time, blocked it. Another chain was emplaced to obstruct the fluvial harbour at Padua, in 1516. This thirty-six-meter long chain was anchored to a strongpoint in the fortifications that encircled the town, the so-called Bastione della Saracinesca. A hand-forged iron chain stretched between Fort Saint Angelo and Fort Saint Elmo also defended the Grand Har- 
bour at Malta. This Chain was approximately two hundred meters in length and permanently anchored (Cubbinson, 2014). Jeffery records how in 1913, he was allowed to convert the Kyrenia Chain tower into "an office and boatshed for the Customs officers" with the especial object of preserving the ancient landmark. As for the chain tower protecting the Kyrenia harbour, we could not establish certainly its construction date, but it is logical to tentatively inscribe it within the medieval fortification of the urban settlement, coevally to the first phase of the castle, in the time of the Byzantine reconquer of the island under the rule of Nicephoros Phokas in 964-965 AD.

\section{Structure from motion photogrammetric survey}

For the interpretation and the correct understanding of the tower, we integrated textual and visual information derived from historical documents with a digital architectural survey. We started this procedure with the acquisition of two different sets of digital photographs. This phase was quite laborious hence the dimensions of the artefact, its position within the harbour surrounded by water and anchored ships and the narrow catwalk surrounding it. From there it was possible to take a complete set of pictures describing the entire outer surface of the tower, but unfortunately with no option of changing the position of the viewpoints as determined by the catwalk. We considered too laborious the option of hiring a boat to circumnavigate the monument, hence the presence of various other vessel anchored around the tower. We could then reach the upper part of the tower, inaccessible to the public, obtaining a permission form the Department of Antiquities and Museums and by borrowing a ladder from the kind workers operating in the closeby shipyard. From there we could shoot a second set of images including though only the upper part of the structure. Two different data sets shot using different cameras and in not simple conditions, were later merged together during the data processing phase. For the data elaboration, we used the Structure from Motion and Image Matching process (SfM/IM), a low-cost close range digital photogrammetric methodology. By using two datasets of pictures and a number of direct survey measures taken with a laser meter, within the photogrammetric procedures we could reconstruct the $3 \mathrm{D}$ position in the space of the $2 \mathrm{D}$ chromatic features detected in each picture. The first result of this process was a 3D point cloud. We then processed the point cloud to extract a 3D surface model, texturized with the chromatic data derived from the digital photographs. For the survey of this tower, we used two different devices and two separated series of pictures to verify how they could be combined within the software and how different digital cameras devices can be used together to produce a unique 3D model. We acquired one set of pictures, for the sidewalls of the tower, with a compact camera and the other one, for the roof, with a smartphone camera ${ }^{1}$. We planned the two sets so to guarantee that a portion of the tower would be included in both. It was possible to join the two point clouds coming from these data sets thanks to using a sufficient number of homologous points. A number of onsite measures taken with the laser meter were useful to calibrate the model's metrical properties. The result of this process was a 3D model ready to be used as a basis for the analysis and the interpretation of data. From the different screenshots generated from the model it was then possible to manually trace with a CAD programme, the elevation and plan drawings as illustrated within this paper. Thanks to the digital photogrammetry technique, it was possible to achieve a complete architectural survey of the monument with no expenses.

\section{Note}

For the tower upper part 160 pictures were acquired with an Apple IPhone 7, ISO 20, focal length 4, F-stop: F/1.8, variable shutter speed, 12 Mpixels resolution, and for the sides 244 pictures were acquired utilising a compact camera, SonyDSC-W730, ISO 80, focal length: 4.5, Fstop: $F / 3.3$ and $F / 8$, variable shutter speed, 16 Mpixels resolution. 

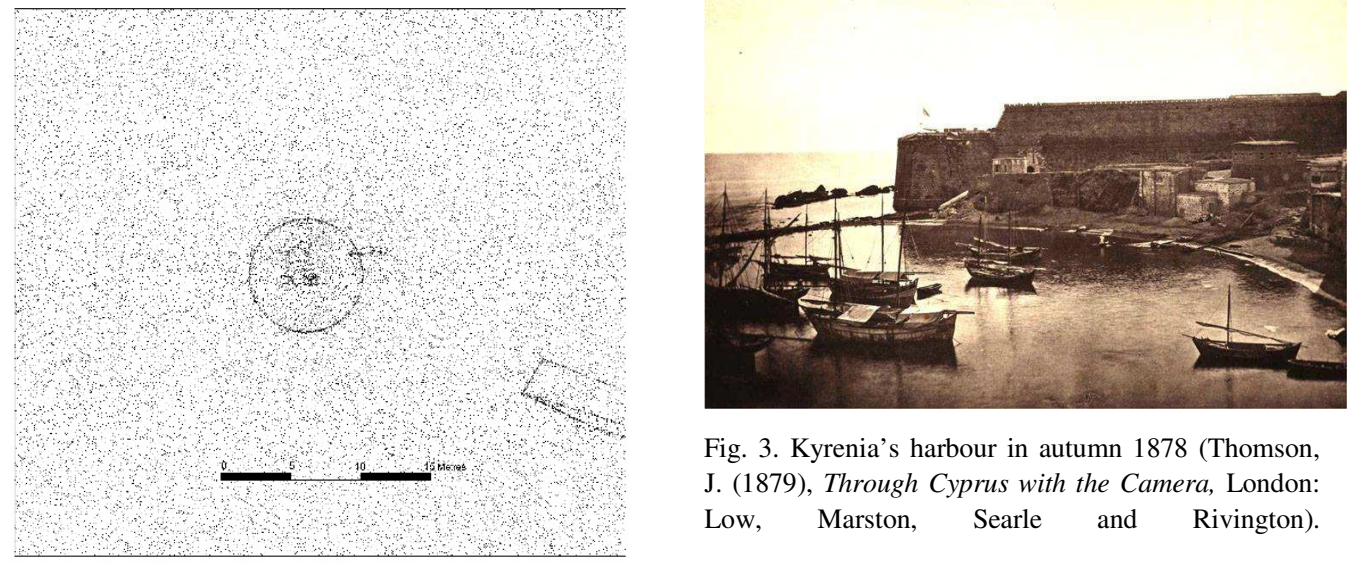

Fig. 3. Kyrenia's harbour in autumn 1878 (Thomson, J. (1879), Through Cyprus with the Camera, London: Low, Marston, Searle and Rivington).

Fig. 2. Kyrenia cadastral plan, detail (Department of Land and Surveys 1960).

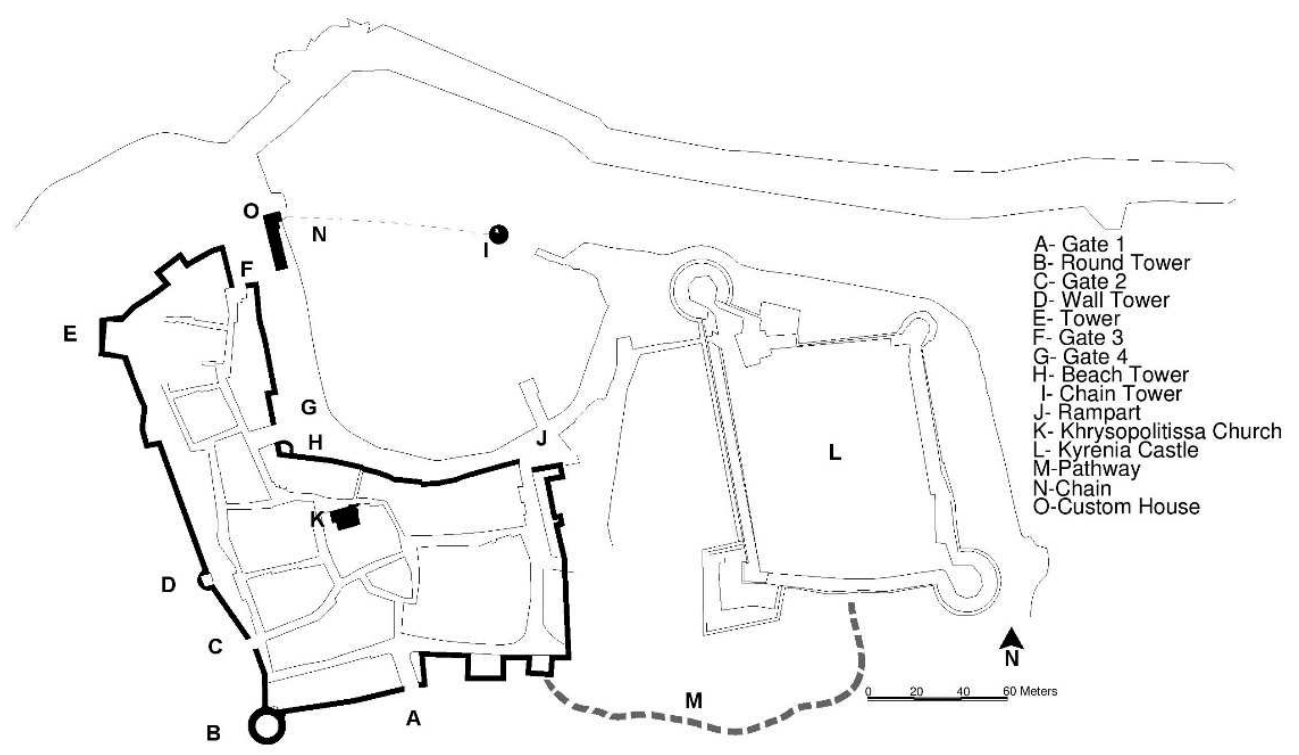

Fig. 4. Kyrenia's fortification system, plan (Baydur, 2017). 


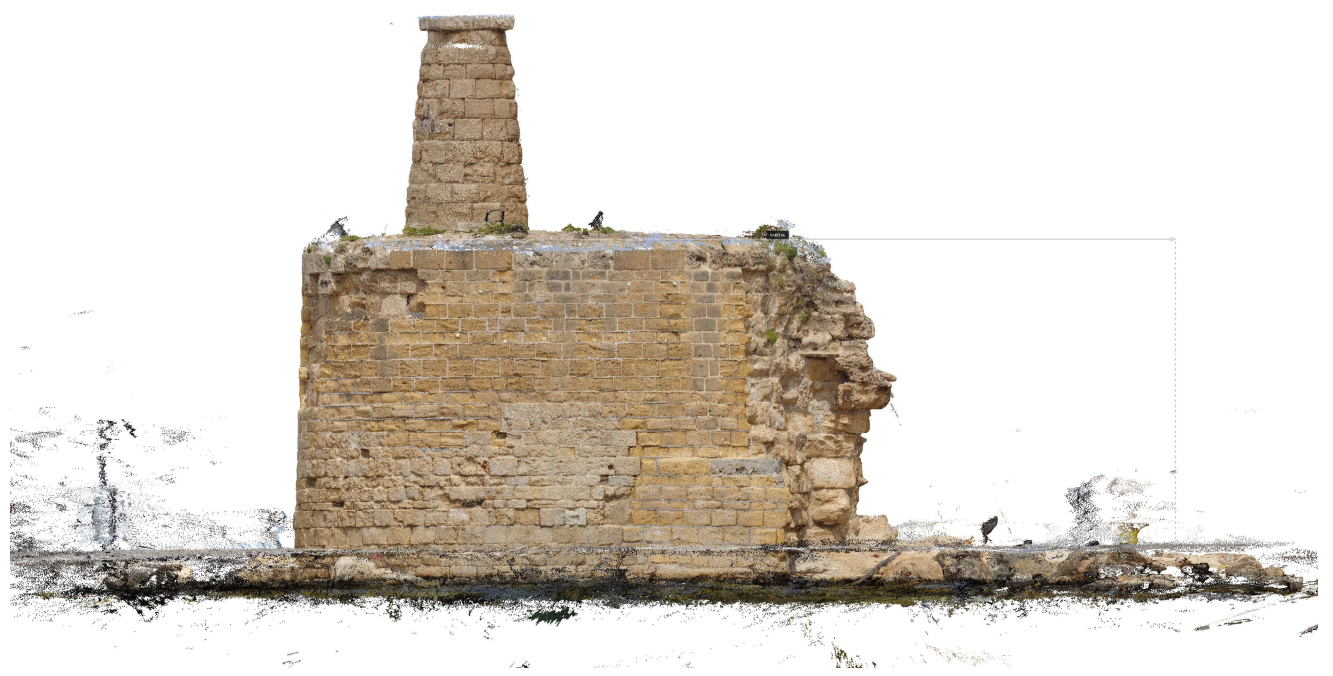

Fig. 5. Rendered south elevation (Griffo, 2018).

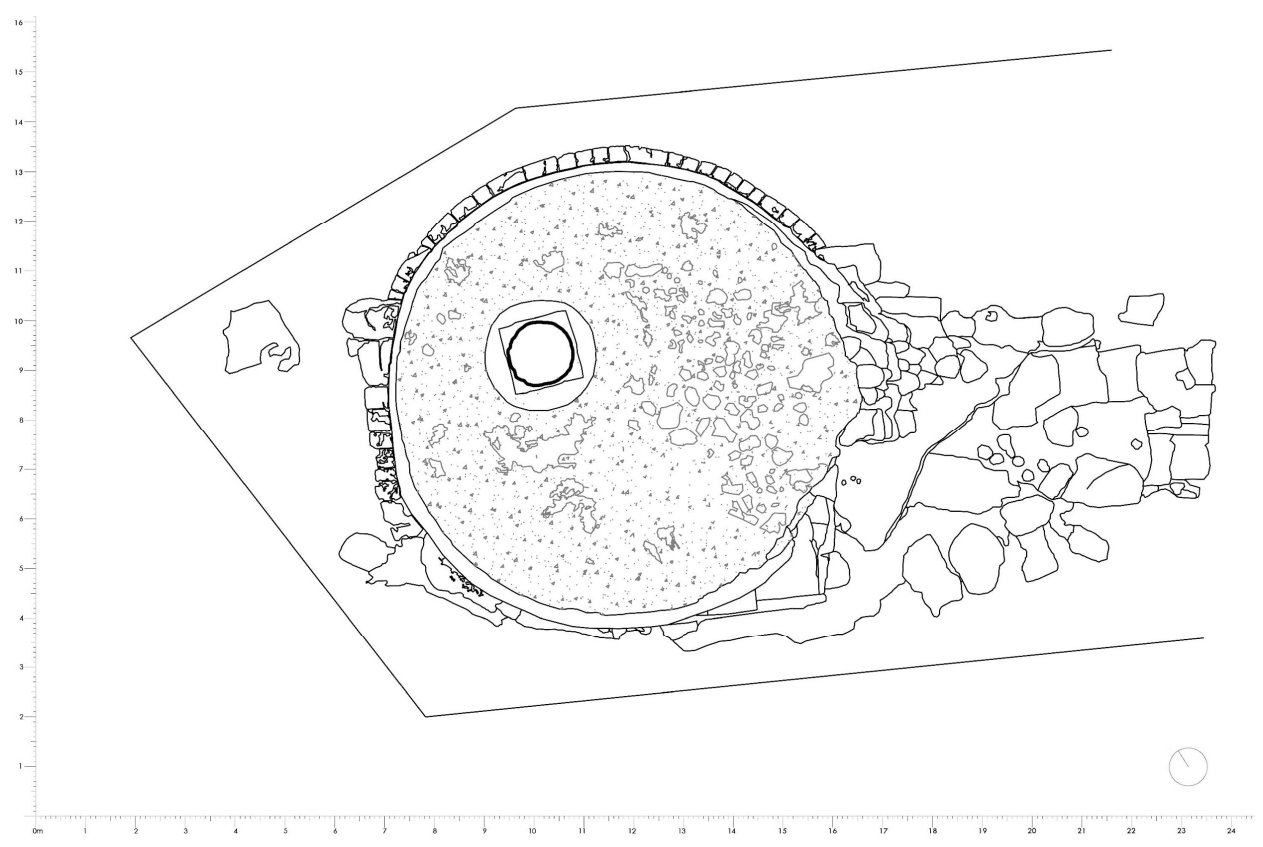

Fig. 6. Roof level plan (Valletta, 2018). 


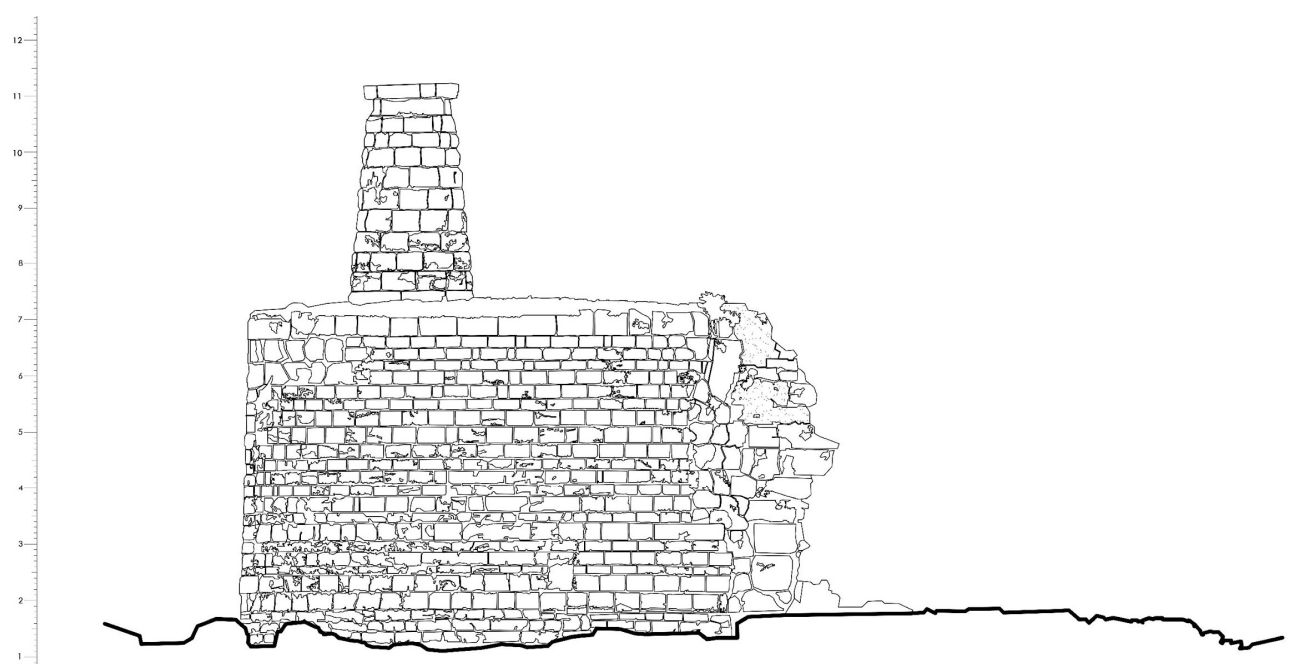

Fig. 7. South elevation (Valletta, 2018).

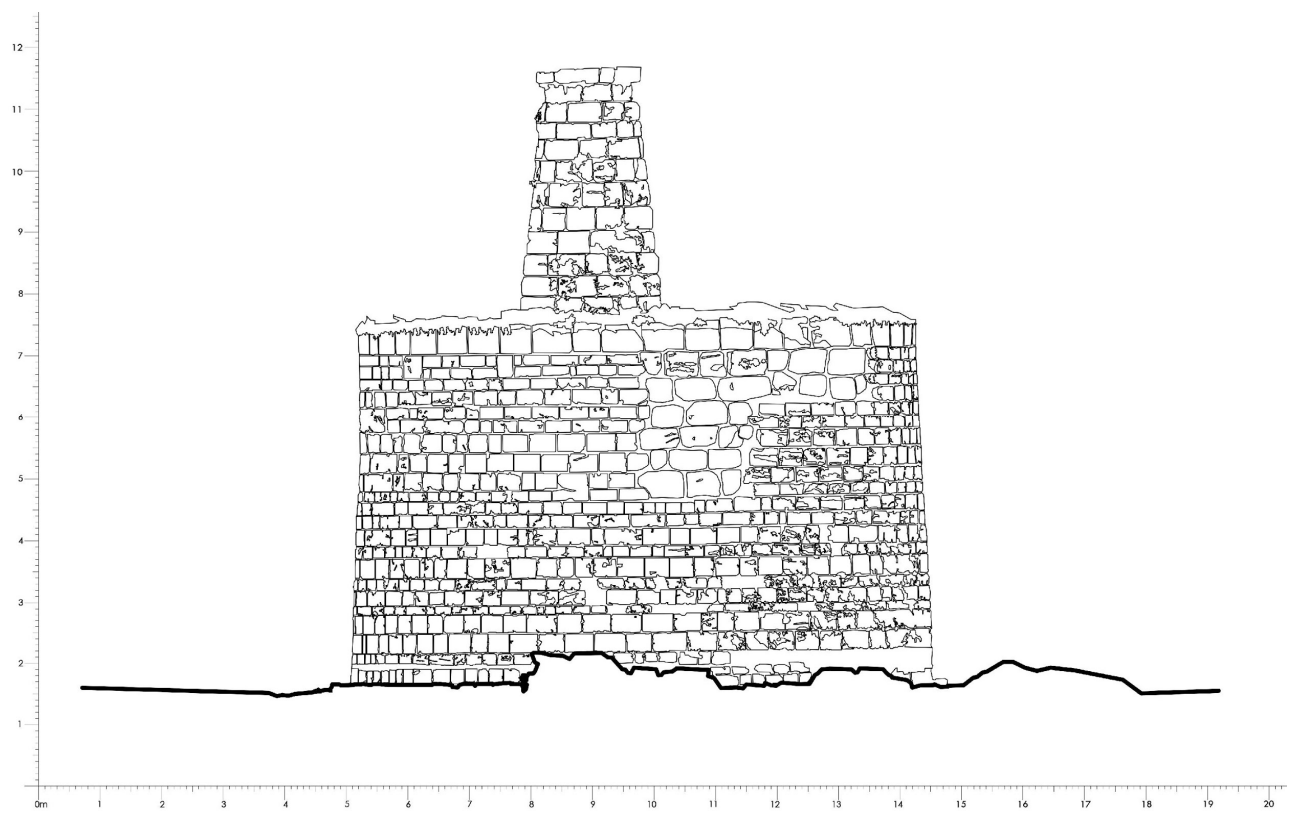

Fig. 8. West elevation (Valletta, 2018). 


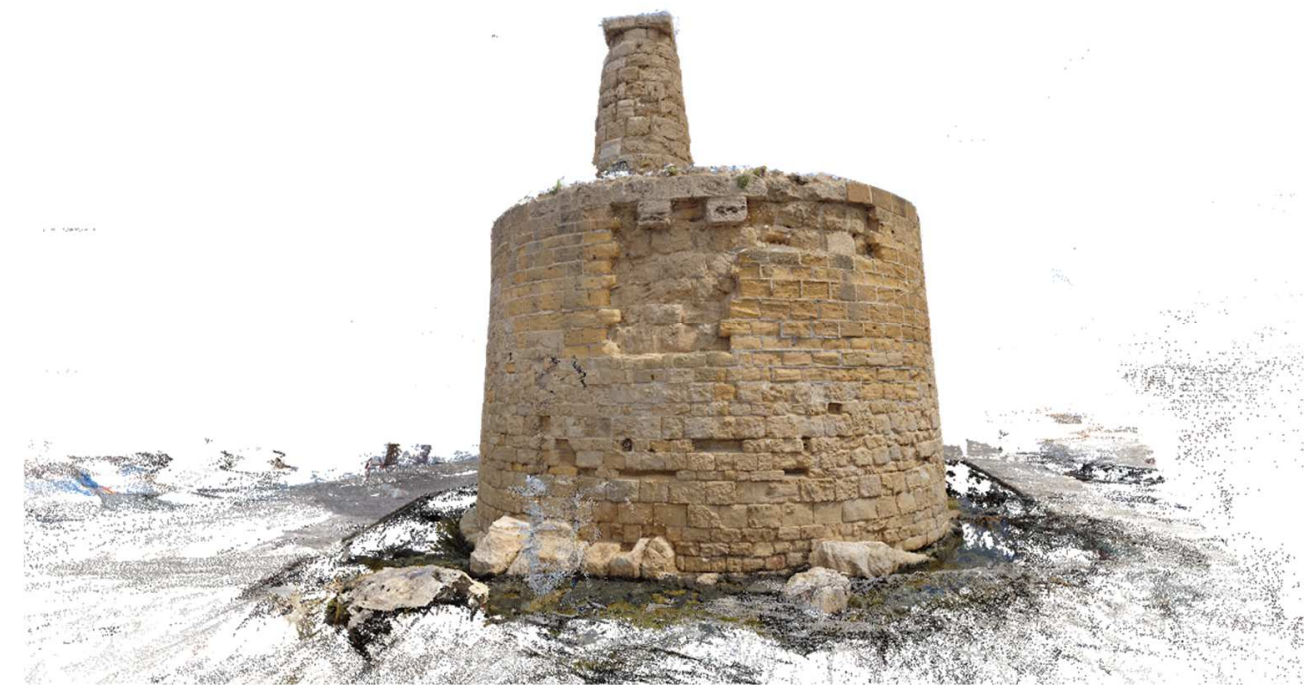

Fig. 9. A rendered west side view of the 3D model, the added stone layer of the modern restoration is clearly visible (Griffo, 2018).

\section{Bibliography}

Arbel, B. (2000). Cyprus, the Franks and Venice, 13th-16th centuries, Variorum Ed., Burlington.

Aristidou, E. (2003). Venetian Rule in Cyprus (1474-1570), Leventis, Nicosia.

Bianchini, C.; Ippolito, A.; Bartolomei C. (2015). "The surveying and representation process applied to architecture: non-contactmethods for the documentation of Cultural Heritage", in Brusaporci, S. ed., Handbook of Research on emerging Digital Tools for Architectural Surveying, Modelling and Representation. Hershey PA: Engineering Science Reference.

Borchardt, K.; Luttrell, A.; Schoffler, E. (2011). Documents concerning Cyprus from the Hospital's Rhodian archives, Cyprus Research Centre, Nicosia.

Camiz, A. (2018). "Storia, tecniche e restauro nell'isola di Cipro. History, techniques and restoration in the island of Cyprus", in Genovese, R.A. ed., Patrimonio e città storiche come poli di integrazione sociale e culturale, sostenibilità e tecnologie innovative. Historic Cities and Heritage as the Hubs of Social and Cultural Integration, Sustainability and Innovative Technologies, Giannini Ed., Napoli, pp. 315-338.

Camiz, A.; Griffo, M.; Valletta, E.; Özen, P. (2018). "The rectangular tower with machicolations of Kyrenia city walls (1191-1228), Cyprus", in Marotta, A.; Spallone, R. eds., FORTMED 2018, Proceedings of the International Conference on Modern Age Fortification of the Mediterranean Coast, Politecnico di Torino, Torino, vol. VIII, pp. 471-478.

Camiz, A.; Griffo, M.; Baydur, S.; Fidan, F.T.; Khalil, S.I. (2017). "The round corner tower of Kyrenia's city walls (1211-1232)", in: González Avilés, A.B. ed., FORTMED 2017. Defensive Architecture of the Mediterranean. XV to XVIII Centuries, Publicacions Universitat d'Alacant, Alacant, vol. 4, pp. 55-62.

Camiz, A.; Verdiani, G.; Ceylanli, Z. (2018). "International workshop: reading and designing the Kyrenia castle", in Bertocci, S. ed., Conference Proceedings of Symposium of representation scientific area for development of multidisciplinary international programs, DIDApress, Florence, pp. 264-269.

Carbonara, G. (1979). La reintegrazione dell'immagine: problemi di restauro dei monumenti, Bulzoni, Rome.

Cubbinson, D.R. (2014). All Canada in the Hands of the British: General Jeffery Amherst and the 1760 Campaign to Conquer New France, University of Oklahoma Press. 
Edbury, P.W. (1991). The Kingdom of Cyprus and the Crusades, 1191-1374, Cambridge University Press, Cambridge.

Enlart, C. (1899). L'art Gothique et la Renaissance en Chypre, Ernest Leroux Éditeur, París.

Gunnis R. (1936). Historic Cyprus: A Guide to its Towns and Villages, Monasteries and Castles, Methuen, London.

Hill, G. (1940). A History of Cyprus. Volume 1: To the Conquest by Richard Lion Heart, Cambridge University Press, Cambridge.

Hill, G. (1948). A History of Cyprus. Volume 2: The Frankish Period 1192-1432, Cambridge University Press, Cambridge.

Jeffery, G. (1918). A description of the Monuments of Cyprus, William James Archer, Nicosia.

Lusignan, E. De. (1573). Chorografia et breve historia universale dell' isola de Cipro principiando al tempo di Nò̀ per in sino al 1572, A. Benaccio, Bologna.

Makhairas, L. (1932). Recital concerning the sweet land of Cyprus entitled 'Chronicle', Clarendon Press, Oxford.

Mas Latrie, M.L. (1861). Histoire de l'ile de Chypre: sous le regne des princes de la maison de Lusignan, Imprimerie imperiale, París, vol. 5.

Megaw, A.H.S. (1951). Repair of ancient monuments 1937-1939, in "Report of the Department of Antiquities Cyprus 1937-1939", Nicosia, p. 179.

Megaw, A.H.S. (1964). Kyrenia castle: a guide, Department of Antiquities of the Republic of Cyprus, Nicosia.

Mol, E. (2012). Hidden Complexities of the Frankish Castle: Social Aspects of Space in the Configurational Architecture of Frankish Castles in the Holy Land, 1099-1291, Leiden University Press, Leiden.

Nicole, D. (2007). Crusader Castles in Cyprus, Greece and the Aegean 1191-1571, Osprey Publishing, London.

Novara, P. de. (1887). Le gestes des Chiprois: recueil de chroniques francaises ecrites en Orient au XIIIe \& XIVe siecles, J.G. Flick, Geneve.

Perbellini, G. (1973). Le Fortificazioni di Cipro dal X al XVI secolo, Istituto Italiano dei Castelli, Roma.

Perbellini, G. (1973). "Le fortificazioni di Cipro dal X al XVI secolo", Castellum. Rivista dell'Istituto italiano dei castelli, 17, pp. 7-58.

Petre, J. (2012). Crusader castles of Cyprus: the fortifications of Cyprus under the Lusignans, 1191-1489, Cyprus Research Centre, Nicosia. 